\title{
Mi residencia en tiempos COVID
}

\section{My residency in COVID times}

Estimado Dr. Carrillo-Esper:

Presente
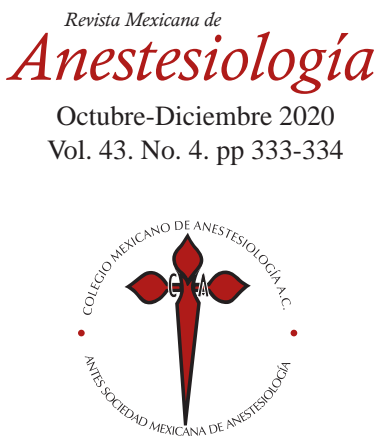

Recibido para publicación: 22/07/2020

Aceptado para publicación: 23/07/2020
No puedes estar enamorado de tus sueños y al mismo tiempo ser amante de tus excusas.

Iván Inzunza
$\mathrm{L}$ a pandemia del coronavirus COVID-19 es la crisis de salud global que define nuestro tiempo y el mayor desafío al que se ha enfrentado desde la Segunda Guerra Mundial. Desde su aparición en Asia, a fines del año pasado, el virus se ha extendido a todos los continentes y ha modificado estilos y formas de vida conocidos; de un momento a otro se inició el confinamiento, la percepción del tiempo se alteró (de tal forma que los días se sentían largos y perdían la necesidad de ser nombrados) y la muerte se convirtió en una constante.

Desde mi perspectiva, todo cambió con intención clara de evitar contagios en masa. Mi hospital sede (soy residente de tercer año en Anestesiología) retiró a los internos de pregrado, decidió guardias mínimas y aislamiento social en seguimiento de indicaciones emitidas por la Secretaría de Salud. Ya en el encierro llegó la incertidumbre, la ansiedad, la depresión, la desconfianza. ¿Qué pasaría con nosotros? ¿Con la especialidad? La información que recibíamos cambiaba constantemente y la preocupación aumentaba a la par de las fases de la pandemia.

Al tiempo que marzo se convierte en domingo y el día siguiente en principio del verano, vi la gran oportunidad de detener esas líneas de pensamiento, valorar las herramientas disponibles y buscar áreas de oportunidad. Para muchos la herramienta de Zoom fue la respuesta, esta plataforma digital permitió formar un grupo de estudio, invitar profesores de alto nivel comprometidos con la enseñanza y avanzar en el programa académico; de igual forma, las redes sociales se convirtieron en aliadas, ya que no sólo son medios distractores, también forma parte de mi avance académico bajo el programa \#AnestesioVirtual. También tuvimos oportunidad de vivir la experiencia única que ofreció el Curso Anual de Anestesiología 2020 del Colegio Mexicano de Anestesiología A.C., que definió una nueva forma de hacer congresos.

Este es un momento histórico al que no hay más que adaptarnos en lo que la vacuna llega a nuestro país y que nos sorprende entre este sinfín de opciones limitadas por la virtualidad, sin poder por esto dejar de lado el hecho de que la medicina es cuestión de práctica real en un cuerpo a cuerpo que no sabe aún de distancias y que nos permitió, desde siempre y hasta antes de ahora, explorar a cada paciente, al punto de abordar casi como propio aquello que impidiera el funcionamiento idóneo de ese universo perfecto que esconde la anatomía humana.

Lejos del duelo y por completo de la mano de las generosas herramientas que la tecnología provee, es difícil escapar a la interrogante de hasta qué punto este confinamiento impuesto por el alto riesgo de contagio del nuevo virus del SARS-CoV-2 hará de nosotros 
médicos probablemente limitados por la información, quizá menos seguros, tal vez más distanciados de la práctica y seguramente muy distintos de todos aquellos que nos precedieron.

Sin embargo, no queda más que continuar con nuestra formación, improvisando espacios, oportunidades y tiempos, pues nuestra especialidad enfrenta hoy retos que sólo superarán aquéllos que hayan transitado con éxito a través de las actuales circunstancias, logrando compensar lo que no se tiene con aquello que sí está por completo en nuestras manos.

\section{Dra. Belén A García-Herrera}

Residente de tercer año en Anestesiología del Hospital Regional de Alta Especialidad de la Península de Yucatán (HRAEPY) Calle 22, Col. Altabrisa, 97133. Mérida, Yucatán. E-mail: iambg525@gmail.com 